\title{
Effect of Storage Temperature on Biochemical and Mixolab Pasting Properties of Chinese Japonica Paddy
}

\author{
Xing-jun $\mathrm{Li}^{1} \&$ Ping Jiang ${ }^{1}$ \\ ${ }^{1}$ Academy of the State Administration of Grains, Beijing 100037, China \\ Correspondence: Xing-jun Li, Academy of the State Administration of Grains, Beijing 100037, China. E-mail: \\ lixingjun3@yahoo.com
}

Received: October 17, 2014 Accepted: December 17, 2014 Online Published: December 29, 2014

doi:10.5539/jfr.v4n2p57

URL: http://dx.doi.org/10.5539/jfr.v4n2p57

\begin{abstract}
This study investigated the changes in germination rate, contents of oleic acids, protein, water soluble sugars, enthalpy of flour gelatinization, and Mixolab dough pasting properties of three varieties of japonica rough rice after 18-month storage at four temperatures of 4,15,25 and $35^{\circ} \mathrm{C}$. After an 18 -month storage, the paddy stored at or below $25{ }^{\circ} \mathrm{C}$ had more than $70 \%$ germination rate, their flour extracts by acid dye mixture of methyl red and bromothymol blue showed greenish color, but the paddy stored at $35^{\circ} \mathrm{C}$ was only $30 \%$ germination rates, their flour extracts by acid dye mixture seem to be yellowish. With an increase in storage temperature, mositure content in paddy decreased, but total protein changed unsignificantly. In comparison to the paddy stored at 15 ${ }^{\circ} \mathrm{C}$, the higher storage temperature $\left(25\right.$ and $\left.35^{\circ} \mathrm{C}\right)$ tends to decrease the contents of damaged starch, water-soluble reducing sugars, total sugars, and uronic acids. The content of oleic acid in paddy stored at $4{ }^{\circ} \mathrm{C}$ was markedly higher than that at the temperatures of 15,25 and $35^{\circ} \mathrm{C}$. Compared to lower temperate $(4$ and 15 ${ }^{\circ} \mathrm{C}$ ), the higher storage temperature $\left(35^{\circ} \mathrm{C}\right)$ increased the gelatinization enthalpy of paddy flour and its starch determined by a differential scanning calorimetry (DSC), also increased Mixolab characteristic torque parameters such as starch gelatinization peak (C3), starch gelatinization minimum (C4), starch retrogradation minimum (C5), degrees of starch decay (C3-C4) and retrogradation (C5-C4) with a decrease in protein weakening $(\mathrm{C} 2)$. The results of this study indicate storage temperature is an important factor affecting the physiological and biochemical properties of paddy, and lower temperature below room temperature are recommended to maintain paddy quality.
\end{abstract}

Keywords: paddy, storage, nutrition, mixolab dough pasting properties, enthalpy of flour gelatinization, ageing

\section{Introduction}

Rice is among the oldest of cultivated crops. History makes first mention of its being grown in China as early as 2800 B.C. Today nearly one half of the world's arable land is used for producing cereal grains, and about one-fifth of this is for the production of rice. As one of primary dietary sources of carbohydrates, rice plays important roles in meeting human energy requirements and nutrient intakes (Yang et al., 2006). China is the world's largest rice producer with annual production over 180 million tonne, and due to its large population, about 40 percent of its production is assigned to store longer periods (two years) in form of paddy under quasi-low temperature (around $20^{\circ} \mathrm{C}$ ) condition. A great deal of studies deal with the effect of short time storage on physicochemical characteristics and rheological properties of rice (Dhaliwal et al., 1991; Likitwattanasade \& Hongsprabhas, 2010; Park et al., 2012 ), but only a few studies (Zhou et al., 2003; 2007; 2010; Zhang et al., 2012) reports the influence of longer time storage on rice deterioration and thermal properties. It is imperative to screen feasible biochemical and thermodynamic parameters for evaluation of paddy quality during storage.

Ageing during storage leads to numerous changes in the chemical and physical properties of rice (Noomhorm et al., 1997; Perdon et al., 1999; Pearce et al., 1999; Suzuki et al., 1999; Sowbhagya \& Bhattacharya, 2001; Zhou et al., 2002; Sodhi et al., 2003; Patindol et al., 2005; Singh et al., 2006; Cao et al., 2009). These changes in rice pasting properties, color, flavor, and composition result in rice cooking and eating quality (Meullenet al., 2000; Teo et al., 2000; Jang et al., 2009) and depend on the rice variety, storage conditions, and amylose content. Such changes have been attributed to changes in cell walls and proteins, interaction between proteins and the degradative products of lipid oxidation, and starch-protein interaction (Sodhi et al., 2003; Park et al., 2012). The rapid viscosity analyzer (RVA) is commonly used to analyze the pasting properties of rice flour suspension 
(Perdon et al., 1997; Sowbhagya \& Bhattacharya, 2001; Zhou et al., 2002), but the mixolab curves could supply with information about water absorption rate, dough protein network and starch gelatinization (Rosell et al., 2007). This study investigated the changes in germination rate, contents of oleic acids and water soluble sugars,damged starch, enthalpy of flour gelatinization, and Mixolab dough pasting properties of three varieties of japonica paddy after 18 -month storage at four temperatures of $4,15,25$ and $35^{\circ} \mathrm{C}$, with an aim to explain the changes in functionality associated with storage.

\section{Method and Materials}

\subsection{Experimental Sample and Preparation}

Three varieties of japonica paddy, "Changyou No. 3", "Wuyuanjng", and "Yanfeng" " were used in this study (Table 1). Yanfeng was harvested in October, 2011 from Panjing city, Liaoning province. Changyou No.3 was obtained in late September, 2011 in Changyou city, Jiangsu province, and Wuyunjing was collected in November 2011 from Nanjing, Jiangsu province. Some samples were cleaned, repacked in 2-kg units in a polyethylene film bags and stored for 18 months in different temperature controller at $4{ }^{\circ} \mathrm{C}, 15{ }^{\circ} \mathrm{C}, 25^{\circ} \mathrm{C}$, or 35 ${ }^{\circ} \mathrm{C}$ before use. The other samples were treated at $40{ }^{\circ} \mathrm{C}$ and $80 \% \mathrm{RH}$ for three days, and then stored at $35^{\circ} \mathrm{C}$, i.e. $40-35^{\circ} \mathrm{C}$ treatment. After storage, the paddy samples were dehulled and milled, with an $800 \mu \mathrm{m}$ screen used.

Table 1. Paddy samples

\begin{tabular}{lll}
\hline Paddy variety (abbr) & Producing region & Harvest time \\
\hline Changyou No. 3 (CY) & Jiangsu Province & Sep. 2011 \\
Wuyunjing (WYJ) & Jiangsu Province & Oct. 2011 \\
Yanfeng (YF) & Jinlin Province & Oct. 2011 \\
\hline
\end{tabular}

\subsection{Moisture Content, Germination Rate and Rice Freshness}

The moisture content of brown rice flour was determined at $105{ }^{\circ} \mathrm{C}$ in an air-oven for $3 \mathrm{~h}$. The germination potential and rate of paddy was determined respectively at the fifth and the tenth day after being seminated at 30 ${ }^{\circ} \mathrm{C}$. Freshness was determined by measuring light transmittance at $620 \mathrm{~nm}$ on rice flour extract with acid dye mixture of $0.05 \%$ methyl red and $0.15 \%$ bromothymol blue.

\subsection{Contents of Free Fatty Acids and Oleic Acid}

The content of free fatty acids (FFA) in rice flour was extracted by anhydrous ethyl alcohol, and then determined by hand titration with $0.01 \mathrm{M}$ sodium hydroxide-ethanol solution using phenolphthalein as indicator. The FFA content was also determined by automatic potentiometric titration method with a potentiometer (ET38, electrode DG 111-SG, Mettler-Toledo).

Oleic acid content in brown rice flour was analyzed by the method of Goffman and Bergman (2003) with some revision. The lipid was extracted by vortex $6 \mathrm{~g}$ of milled rice for $15 \mathrm{~min}$ with $10 \mathrm{ml}$ of isooctane, and then centrifuged at $4000 \mathrm{rpm}$ for $5 \mathrm{~min}$ to collect the supernatant. An assay solution containing $4 \mathrm{ml}$ of isooctane extract and $2 \mathrm{ml}$ of $3 \%$ pyridine $/ 5 \%$ cupric acetate reagent was shaken $5 \mathrm{~min}$. After aqueous phase was fully fractionated, take $1 \mathrm{~mL}$ isooctane fraction with a pipette to place in a 1-cm cuvette and measure absorbance at $715 \mathrm{~nm}$. The oleic acid content of each extract was obtained from a calibration curve. Oleic acid (Sigma) was dissolved in isooctane to produce oleic acid solutions of $0-14.5 \mu \mathrm{mol} / \mathrm{ml}$.

\subsection{Content of-Soluble Total Sugars, Reducing Sugars and Pectic Acids of Paddy}

Brown rice flour $(1.0 \mathrm{~g})$ was weighed into $50 \mathrm{ml}$ plastic centrifuge tube, mixed with $15 \mathrm{ml}$ of hexane, and then shaken at room temperature for $3 \mathrm{~h}$. After centrifuged at $4000 \mathrm{rpm}$ and $4{ }^{\circ} \mathrm{C}$ for $10 \mathrm{~min}$, the precipitate was kept and fully volatilized hexane at a fume hood. The defatted meal was ground using a pestle and mortal with $15 \mathrm{ml}$ of distilled water, then extracted for $5 \mathrm{~min}$ at room temperature. After centrifuged at $4000 \mathrm{rpm}$ for $10 \mathrm{~min}$, the supernatant was sample extracts. The content of total sugars was determined using phenol- sulfuric acid (Dubois et al., 1956). The extract $(0.5 \mathrm{ml})$ was added $0.5 \mathrm{ml}$ of $5 \%$ phenol aqueous solution, then $3 \mathrm{ml}$ sulfuric acid, and carefully shaken. After cooled, the absorbency of $490 \mathrm{~nm}$ was measured.

The content of reducing sugars was determined by 3,5-dinitro salicylic acid (DNS) colorimetric method. The extract $(800 \mu \mathrm{l})$ was mixed with $600 \mathrm{ul}$ of $4.4 \mathrm{mM}$ DNS reagent, and boiled in water bath for $5 \mathrm{~min}$. After cooled, 
the solution was diluted to a volume of $10 \mathrm{ml}$ with distilled water and the absorbency of $540 \mathrm{~nm}$ was measured. Glucose was used to make standard curve.

Uronic acid content was determined as described by Blumenkrantz et al. (1973). The extract ( $0.5 \mathrm{ml})$ was added $3 \mathrm{ml}$ of $12.5 \mathrm{mM}$ sodium tetraborate/ sulfuric acid, mixed, and boiled in water bath for $5 \mathrm{~min}$. After cooled on ice to room temperature, the reactant was added $50 \mu \mathrm{l}$ of $0.15 \%$ m-hydroxydipheny/ $0.5 \% \mathrm{NaOH}$ reagent, mixed and the absorbency of $520 \mathrm{~nm}$ was measured. Galacturonic acid (sigma) was used to make standard curve.

\subsection{Contents of Protein and Damaged Starch of Paddy}

The protein content in brown rice flour was determined by automatic nitrogen element rapid analyzer (Carbon Hydrogen Nitrogen Element Analyzer M366774, Elementar, Germany), the measured value was multiplied a coefficient of 5.95 .

The damaged starch content was determined by SD matic analyzer (Chopin Technologies, France). One gram rice flour was weighed and put into small dipper of the analyzer, one drop of $95 \%$ ethanol, $3 \mathrm{~g}$ boric acid, $3 \mathrm{~g}$ potassium iodide and $120 \mathrm{ml}$ distilled water were put into the reaction cup. The analyzer automatically raises temperature of the reaction cup to $35^{\circ} \mathrm{C}$, and flour sample automatically falls into reaction cup. This analyzer automatically calculates the content of damaged starch based on the residual iodide concentration. The result was present as the percentage of iodine adsorption ( $\mathrm{Ai} \%)$, since the content of damaged starch in brown rice flour expressed by either the UCD unit (the instrument manufacturer supply the calculation method) or UCDC unit (consider the effect of moisture and protein based on the UCD calculation) is negative.

\subsection{Gelatinization Properties}

The thermal properties of rice flour and purified starch were determined with a different scanning calorimeter (DSC) 200F3 (Netzsch, Germany). The sample (3.0-3.1 mg) was weighed at aluminium crucible and added distilled water to the ratio of water/sample as $2: 1$. The aluminium crucible was sealed and equilibrated at $4{ }^{\circ} \mathrm{C}$ overnight. DSC temperature was raised from 30 to $110^{\circ} \mathrm{C}$, with heating rate $10^{\circ} \mathrm{C} / \mathrm{min}$.

Rice starch was isolated by combining $3 \mathrm{~g}$ brown rice flour with $30 \mathrm{ml}$ of petroleum ether/anhydrous ethanol $(\mathrm{v} / \mathrm{v}, 4: 1)$ and shaking for $2 \mathrm{~h}$ at room temperature to defat. After centrifuged at $4000 \mathrm{rpm}$ for $10 \mathrm{~min}$, the residue was again added $30 \mathrm{ml}$ of petroleum ether/anhydrous ethanol (v/v, 4:1) and shaken for $2 \mathrm{~h}$. The precipitate was dipped in $12 \mathrm{ml}$ of $0.1 \% \mathrm{Na}_{2} \mathrm{SO}_{3}$ solution for $1 \mathrm{~h}$, and then centrifuged at $4000 \mathrm{rpm}$ for $10 \mathrm{~min}$. The precipitate was dissolved by $30 \mathrm{ml}$ of $1 \%$ SDS solution and shaken $4 \mathrm{~h}$. After centrifuged, the residue was washed four times with distilled water. Finally, the starch solid was dried at $45^{\circ} \mathrm{C}$ over $5 \mathrm{~h}$.

\subsection{Mixolab Measurement}

The mixing and pasting behavior of rice flour dough was measured using a Mixolab (Chopin Technologies, France) according to Rosell et al. (2007). Dough weighed at $90 \mathrm{~g}$ with $60 \%$ of water (14\% w.b.) was evaluated. Both initial mixing temperature and water tank temperature were $30{ }^{\circ} \mathrm{C}$. The hydration was $55 \%-65 \%$. Target torque is $0.8 \pm 0.5 \mathrm{Nm}$. The mixing speed during the entire assay was $80 \mathrm{rpm} / \mathrm{min}$. Firstly, the temperature was held at $30^{\circ} \mathrm{C}$ for $8 \mathrm{~min}$ for the initial mixing. Secondly, the temperature increased at $4{ }^{\circ} \mathrm{C} / \mathrm{min}$ to $90^{\circ} \mathrm{C}$ within 15 min and then held for $7 \mathrm{~min}$. Thirdly, the temperature decreased at $4{ }^{\circ} \mathrm{C} / \mathrm{min}$ to $50{ }^{\circ} \mathrm{C}$ within $10 \mathrm{~min}$ and held for $5 \mathrm{~min}$. The total test time is $45 \mathrm{~min}$. The parameters of interest, given in $\mathrm{Nm}$ and including $\mathrm{C} 1-\mathrm{C} 2$ as well as C3-C4 and C5-C4, were recorded and calculated.

\subsection{Statistical Analysis}

Experimental data were subjected to analysis of variance using SPSS 11.5 for windows. Treatment means were tested separately for least significant difference at a $5 \%$ level of probability.

\section{Results}

\subsection{Changes in Moisture Content, Germination Rate and Freshness of Paddy}

Table 2 shows the changes in moisture content, germination rate and freshness of paddy. The moisture content (m.c.) of paddy decreased with an increase in storage temperature. The germination potential and rate of three japonica paddy tended to decrease with increaseing storage temperature. Stored at $35{ }^{\circ} \mathrm{C}$ for 15 months, Changyou and Wuyunjing did not germinate, Yanfeng germinated $31 \%$. At $25^{\circ} \mathrm{C}$ storage condition, Changyou, Wuyunjing, and Yanfeng germinated $72 \%, 85 \%, 92 \%$, respectively. At lower temperature $\left(15^{\circ} \mathrm{C}\right)$ storage, their germination rates all were over $95 \%$.

The brown rice flour extracts by acid dye mixture of methyl red and bromothymol blue show that the paddy stored at $4{ }^{\circ} \mathrm{C}$ to $25^{\circ} \mathrm{C}$ gave grass green or greenish color, but paddies stored at $35^{\circ} \mathrm{C}$ was yellowish, even brown. 
The acid dye extracts from paddy stored at higher temperature had higher transparency $\left(\mathrm{T}_{620}\right)$ than those of paddy stored at $4{ }^{\circ} \mathrm{C}$.

Table 2. Germination rate and freshness of paddy stored for eighteen months

\begin{tabular}{lllllll}
\hline Rice & Storage & Moisture content & Germination & Germination & Freshness & \\
\cline { 6 - 7 } variety & Temp $\left({ }^{\circ} \mathrm{C}\right)$ & $(\%)$ & Potential $(\%)$ & Rate $(\%)$ & $\mathrm{T}_{620}$ & Color \\
\hline CY & 4 & 14.71 & $95.7 \pm 4.9 \mathrm{a}$ & $96.0 \pm 4.4 \mathrm{a}$ & $18.45 \pm 0.04 \mathrm{e}$ & greenish \\
& 15 & 14.33 & $93.0 \pm 1.0 \mathrm{a}$ & $95.0 \pm 1.7 \mathrm{a}$ & $31.88 \pm 0.01 \mathrm{~b}$ & greenish \\
& 25 & 13.63 & $65.7 \pm 2.1 \mathrm{~b}$ & $72.0 \pm 3.6 \mathrm{~b}$ & $26.57 \pm 0.03 \mathrm{~d}$ & greenish \\
& 35 & 13.28 & $0 \pm 0 \mathrm{c}$ & $0 \pm 0 \mathrm{c}$ & $71.76 \pm 0.06 \mathrm{a}$ & yellowish \\
& $40-35$ & 12.07 & $0 \pm 0 \mathrm{c}$ & $1.0 \pm 1.7 \mathrm{c}$ & $31.02 \pm 0.02 \mathrm{c}$ & yellowish \\
\hline WYJ & 4 & 14.75 & $95.7 \pm 2.1 \mathrm{a}$ & $97.0 \pm 2.6 \mathrm{a}$ & $16.31 \pm 0.06 \mathrm{e}$ & greenish \\
& 15 & 13.35 & $97.7 \pm 1.5 \mathrm{a}$ & $98.3 \pm 0.6 \mathrm{a}$ & $34.26 \pm 0.04 \mathrm{a}$ & greenish \\
& 25 & 12.90 & $91.3 \pm 1.5 \mathrm{ab}$ & $92.3 \pm 2.5 \mathrm{ab}$ & $27.35 \pm 0.05 \mathrm{~d}$ & greenish \\
& 35 & 11.49 & $0 \pm 0 \mathrm{~d}$ & $0 \pm 0 \mathrm{~d}$ & $33.46 \pm 0.03 \mathrm{~b}$ & yellowish \\
& $40-35$ & 10.85 & $1.0 \pm 0 \mathrm{c}$ & $1.3 \pm 0.6 \mathrm{c}$ & $29.70 \pm 0.02 \mathrm{c}$ & yellowish \\
\hline YF & 4 & 13.92 & $86.3 \pm 0.6 \mathrm{a}$ & $91.3 \pm 3.1 \mathrm{a}$ & $19.46 \pm 0.03 \mathrm{e}$ & greenish \\
& 15 & 13.17 & $91.7 \pm 2.9 \mathrm{a}$ & $95.0 \pm 2.6 \mathrm{a}$ & $24.57 \pm 0.17 \mathrm{~d}$ & greenish \\
& 25 & 12.41 & $81.0 \pm 1.7 \mathrm{~b}$ & $84.7 \pm 2.5 \mathrm{~b}$ & $25.65 \pm 0.07 \mathrm{c}$ & greenish \\
& 35 & 10.76 & $29.0 \pm 2.6 \mathrm{c}$ & $31.3 \pm 3.1 \mathrm{c}$ & $28.95 \pm 0.01 \mathrm{a}$ & yellowish \\
& $40-35$ & 9.91 & $1.7 \pm 0.6 \mathrm{~d}$ & $6.3 \pm 3.5 \mathrm{~d}$ & $26.79 \pm 0.08 \mathrm{~b}$ & yellowish \\
\hline
\end{tabular}

Data are given as the means $\pm \mathrm{SD}$ (standard deviation) for triplicate.

\subsection{Changes in Free Fatty Acid (FAA) and Oleic Acid of Paddy}

Table 3. Fatty acid content of paddy stored for eighteen months

\begin{tabular}{lllll}
\hline & Storage temp. $\left({ }^{\circ} \mathrm{C}\right)$ & CY & WYJ & YF \\
\hline Free fatty acids & 4 & $23.01 \pm 7.53 \mathrm{~b}$ & $32.97 \pm 2.85 \mathrm{~b}$ & $8.15 \pm 2.82 \mathrm{c}$ \\
$(\mathrm{mgKOH} / 100 \mathrm{~g})$ & 15 & $65.35 \pm 2.26 \mathrm{a}$ & $52.51 \pm 5.69 \mathrm{a}$ & $44.39 \pm 17.09 \mathrm{~b}$ \\
Hand titration & 25 & $59.99 \pm 2.34 \mathrm{a}$ & $60.31 \pm 7.94 \mathrm{a}$ & $39.16 \pm 12.44 \mathrm{~b}$ \\
& 35 & $64.58 \pm 10.43 \mathrm{a}$ & $60.90 \pm 5.61 \mathrm{a}$ & $90.3 \pm 7.74 \mathrm{a}$ \\
& $40-35$ & $47.76 \pm 15.76 \mathrm{a}$ & $0 \pm 0 \mathrm{c}$ & $31.03 \pm 0 \mathrm{~b}$ \\
\hline Free fatty acids & 4 & $44.44 \pm 0.37 \mathrm{~b}$ & $52.47 \pm 1.02 \mathrm{a}$ & $62.80 \pm 4.42 \mathrm{a}$ \\
$($ mgKOH/100g) & 15 & $45.92 \pm 2.44 \mathrm{~b}$ & $43.58 \pm 0.71 \mathrm{c}$ & $46.72 \pm 0.96 \mathrm{e}$ \\
Potentiometric & 25 & $45.54 \pm 2.43 \mathrm{~b}$ & $48.96 \pm 2.02 \mathrm{~b}$ & $48.71 \pm 0.32 \mathrm{c}$ \\
titration & 35 & $66.18 \pm 3.68 \mathrm{a}$ & $49.08 \pm 2.12 \mathrm{~b}$ & $48.08 \pm 0.19 \mathrm{~d}$ \\
& $40-35$ & $45.21 \pm 1.17 \mathrm{~b}$ & $48.19 \pm 1.80 \mathrm{~b}$ & $53.38 \pm 2.09 \mathrm{~b}$ \\
\hline Oleic acid & 4 & $938.36 \pm 55.91 \mathrm{a}$ & $2202.76 \pm 27.28 \mathrm{a}$ & $1517.34 \pm 85.94 \mathrm{a}$ \\
$(\mu \mathrm{g} / \mathrm{gdw})$ & 15 & $403.81 \pm 9.65 \mathrm{e}$ & $608.42 \pm 10.53 \mathrm{c}$ & $651.75 \pm 5.95 \mathrm{c}$ \\
& 25 & $495.22 \pm 26.21 \mathrm{c}$ & $522.49 \pm 6.18 \mathrm{~d}$ & $698.28 \pm 11.6 \mathrm{~b}$ \\
& 35 & $567.51 \pm 43.79 \mathrm{~b}$ & $869.90 \pm 37.78 \mathrm{~b}$ & $696.12 \pm 3.22 \mathrm{~b}$ \\
& $40-35$ & $459.23 \pm 6.07 \mathrm{~d}$ & $432.9 \pm 20.52 \mathrm{~d}$ & $657.07 \pm 16.46 \mathrm{c}$ \\
\hline
\end{tabular}

Data are given as the means \pm SD for triplicate. 
Table 3 shows changes in the content of paddy FAA determined by different methods. With phenolphthalein as an indicator, the $\mathrm{KOH}$ - ethanol solution was used to manually titrate the paddy FFA extracted by anhydrous ethyl ethanol solution. The FFA in paddy stored at $15{ }^{\circ} \mathrm{C}$ to $35^{\circ} \mathrm{C}$ was clearly higher than that stored at $4{ }^{\circ} \mathrm{C}$. The paddy FFA measured by this method did not show linear relationship with storage temperature in the range of 15 ${ }^{\circ} \mathrm{C}$ to $35^{\circ} \mathrm{C}$.

The paddy FFA extracted by anhydrous ethyl ethanol was titrated with $\mathrm{KOH}$ - ethanol solution using potentiotitration method and $\mathrm{pH}$ glass electrode as indicating electrode. With addition of titration reagent, the potential $(\mathrm{E})$ changed with the volume $(\mathrm{V})$ of titration reagent. When $\mathrm{E}$ occur a transition, the end of titration reached. The FFA contents in Wuyun jing and Yanfeng stored at 15 to $35^{\circ} \mathrm{C}$ were clearly lower than that stored at $4{ }^{\circ} \mathrm{C}$, but Changyou stored at 15 to $35^{\circ} \mathrm{C}$ had higher FFA content than at $4{ }^{\circ} \mathrm{C}$.

The paddy FFA content was also determined by colorimetric method with cupric acetate-pyridine as a color developing reagent. The oleic acid was used to make standard curve. The content of oleic acid in paddy stored at $4{ }^{\circ} \mathrm{C}$ was markedly higher than that at the temperatures of $15^{\circ} \mathrm{C}, 25^{\circ} \mathrm{C}$ and $35^{\circ} \mathrm{C}$.

\subsection{Changes in Water-Soluble Sugars, Crude Protein and Damaged Starch of Paddy}

Table 4. Changes in water-soluble sugars, protein and damaged starch of paddy stored for eighteen months

\begin{tabular}{|c|c|c|c|c|c|c|}
\hline $\begin{array}{l}\text { Rice } \\
\text { variety }\end{array}$ & $\begin{array}{l}\text { Storage } \\
\text { temp. } \\
\left({ }^{\circ} \mathrm{C}\right)\end{array}$ & $\begin{array}{l}\text { Reducing } \\
\text { sugars } \\
(\mathrm{mg} / \mathrm{g} \mathrm{dw})\end{array}$ & $\begin{array}{l}\text { Total sugars } \\
(\mathrm{mg} / \mathrm{g} \mathrm{dw})\end{array}$ & $\begin{array}{l}\text { Pectic acids } \\
(\mathrm{mg} / \mathrm{g} \mathrm{dw})\end{array}$ & $\begin{array}{l}\text { Protein } \\
\text { (\%d.b.) }\end{array}$ & $\begin{array}{l}\text { Iodine value } \\
\text { (Ai\%) }\end{array}$ \\
\hline \multirow[t]{5}{*}{$\mathrm{CY}$} & 4 & $7.56 \pm 0.64 d$ & $27.83 \pm 1.41 \mathrm{a}$ & $0.68 \pm 0.01 \mathrm{~cd}$ & 8.81 & $80.47 \pm 0.06 b$ \\
\hline & 15 & $17.96 \pm 0.09 \mathrm{a}$ & $25.07 \pm 0.24 \mathrm{~b}$ & $1.03 \pm 0.01 \mathrm{a}$ & 8.98 & $81.52 \pm 0.58 \mathrm{a}$ \\
\hline & 25 & $13.68 \pm 0.64 b$ & $22.59 \pm 0.40 \mathrm{c}$ & $0.79 \pm 0.06 \mathrm{c}$ & 8.81 & $78.23 \pm 0.23 \mathrm{c}$ \\
\hline & 35 & $13.44 \pm 0.14 \mathrm{~b}$ & $17.90 \pm 1.86 \mathrm{~d}$ & $0.72 \pm 0.07 \mathrm{c}$ & 8.79 & $77.36 \pm 0.38 \mathrm{~d}$ \\
\hline & $40-35$ & $8.88 \pm 0.67 \mathrm{c}$ & $20.17 \pm 1.38 \mathrm{~d}$ & $0.96 \pm 0.05 b$ & 8.88 & $75.85 \pm 0.36 \mathrm{e}$ \\
\hline \multirow[t]{5}{*}{ WYJ } & 4 & $8.23 \pm 0.07 \mathrm{c}$ & $21.30 \pm 0.94 b$ & $0.30 \pm 0.01 \mathrm{~d}$ & 10.03 & $82.47 \pm 0.47 a$ \\
\hline & 15 & $15.04 \pm 0.42 \mathrm{a}$ & $27.62 \pm 1.97 \mathrm{a}$ & $1.20 \pm 0.05 \mathrm{a}$ & 10.29 & $78.49 \pm 0.22 b$ \\
\hline & 25 & $11.38 \pm 0.25 b$ & $21.29 \pm 0.75 b$ & $0.77 \pm 0.06 \mathrm{c}$ & 10.21 & $78.45 \pm 0.30 \mathrm{~b}$ \\
\hline & 35 & $11.80 \pm 0.24 \mathrm{~b}$ & $20.96 \pm 0.40 \mathrm{~b}$ & $0.87 \pm 0.02 \mathrm{~b}$ & 10.11 & $77.50 \pm 0.34 \mathrm{c}$ \\
\hline & $40-35$ & $8.59 \pm 0.51 \mathrm{c}$ & $21.60 \pm 1.02 \mathrm{~b}$ & $0.92 \pm 0.03 \mathrm{~b}$ & 9.93 & $75.96 \pm 0.05 \mathrm{~d}$ \\
\hline \multirow[t]{5}{*}{ YF } & 4 & $12.88 \pm 0.36 \mathrm{~b}$ & $19.45 \pm 0.64 \mathrm{ab}$ & $0.71 \pm 0.01 \mathrm{c}$ & 10.07 & $80.03 \pm 0.13 a$ \\
\hline & 15 & $15.66 \pm 0.12 \mathrm{a}$ & $21.66 \pm 1.57 \mathrm{a}$ & $1.01 \pm 0.02 \mathrm{a}$ & 9.21 & $76.56 \pm 0.59 \mathrm{~b}$ \\
\hline & 25 & $14.27 \pm 0.48 \mathrm{a}$ & $21.83 \pm 1.17 \mathrm{a}$ & $0.87 \pm 0.07 \mathrm{ab}$ & 10.72 & $73.60 \pm 0.12 \mathrm{c}$ \\
\hline & 35 & $11.85 \pm 0.57 \mathrm{c}$ & $19.81 \pm 0.87 \mathrm{a}$ & $0.95 \pm 0.05 \mathrm{a}$ & 11.36 & $73.02 \pm 0.42 \mathrm{~d}$ \\
\hline & $40-35$ & $8.09 \pm 0.47 \mathrm{~d}$ & $20.61 \pm 1.59 \mathrm{a}$ & $0.65 \pm 0.06 \mathrm{c}$ & 10.43 & $72.36 \pm 0.53 \mathrm{~d}$ \\
\hline
\end{tabular}

Data are given as the mean \pm SD for triplicate. The protein content is the mean of two deterimations.

Table 4 shows the changes in water-soluble reducing sugar, total sugar, pectic acid, and crude protein, as well as damaged starch of paddy. In comparison to $15^{\circ} \mathrm{C}$ storage, the contents of water-soluble reducing sugar, total sugar, and pectic acid tended to decrease in paddy stored at $25^{\circ} \mathrm{C}$ to $35^{\circ} \mathrm{C}$. The content of paddy crude protein changed insignificantly with an increase in storage temperature. Compared to $4{ }^{\circ} \mathrm{C}$ and $15{ }^{\circ} \mathrm{C}$ storage, the damaged starch in paddy stored at $25^{\circ} \mathrm{C}$ and $35^{\circ} \mathrm{C}$ was reduced. 


\subsection{Changes in Thermal Properties of Paddy}

Table 5. DSC data for rice flour ground from paddy storage for eighteen months

\begin{tabular}{llllllll}
\hline $\begin{array}{l}\text { Rice } \\
\text { Variety }\end{array}$ & $\begin{array}{l}\text { Storage temp. } \\
\left({ }^{\circ} \mathrm{C}\right)\end{array}$ & $\begin{array}{l}\mathrm{T}_{\mathrm{o}} \\
\left({ }^{\circ} \mathrm{C}\right)\end{array}$ & $\begin{array}{l}\mathrm{T}_{\mathrm{p}} \\
\left({ }^{\circ} \mathrm{C}\right)\end{array}$ & $\begin{array}{l}\mathrm{T}_{\mathrm{c}} \\
\left({ }^{\circ} \mathrm{C}\right)\end{array}$ & $\begin{array}{l}\text { Peak width } \\
\left({ }^{\circ} \mathrm{C}\right)\end{array}$ & $\begin{array}{l}\text { Peak enthalpy } \\
(\mathrm{W} / \mathrm{mg})\end{array}$ & $\begin{array}{l}\Delta \mathrm{H} \\
(\mathrm{J} / \mathrm{g} \text { flour })\end{array}$ \\
\hline $\mathrm{CY}$ & 4 & $61.8 \pm 0.4 \mathrm{a}$ & $67.2 \pm 0.4 \mathrm{a}$ & $72.9 \pm 0.5 \mathrm{a}$ & $11.1 \pm 0.9 \mathrm{a}$ & $0.1132 \pm 0.0094 \mathrm{a}$ & $5.5193 \pm 0.775 \mathrm{~b}$ \\
& 15 & $61.5 \pm 0.2 \mathrm{a}$ & $66.9 \pm 0.3 \mathrm{a}$ & $72.3 \pm 0.6 \mathrm{a}$ & $10.8 \pm 0.4 \mathrm{a}$ & $0.1131 \pm 0.0145 \mathrm{a}$ & $5.724 \pm 0.503 \mathrm{~b}$ \\
& 25 & $61.7 \pm 0.6 \mathrm{a}$ & $67.0 \pm 0.3 \mathrm{a}$ & $72.5 \pm 0.9 \mathrm{a}$ & $10.8 \pm 0.6 \mathrm{a}$ & $0.1121 \pm 0.0129 \mathrm{a}$ & $5.254 \pm 0.894 \mathrm{~b}$ \\
& 35 & $61.7 \pm 0.4 \mathrm{a}$ & $67.4 \pm 0.2 \mathrm{a}$ & $74.0 \pm 0.6 \mathrm{a}$ & $12.3 \pm 1.7 \mathrm{a}$ & $0.1122 \pm 0.0122 \mathrm{a}$ & $7.145 \pm 0.549 \mathrm{a}$ \\
& $40-35$ & $61.8 \pm 0.2 \mathrm{a}$ & $67.3 \pm 0.2 \mathrm{a}$ & $73.1 \pm 0.5 \mathrm{a}$ & $11.3 \pm 0.5 \mathrm{a}$ & $0.1206 \pm 0.0116 \mathrm{a}$ & $7.0170 \pm 0.672 \mathrm{a}$ \\
WYJ & 4 & $64.7 \pm 0.8 \mathrm{a}$ & $70.7 \pm 0.5 \mathrm{ab}$ & $77.1 \pm 0.7 \mathrm{a}$ & $12.0 \pm 1.2 \mathrm{a}$ & $0.1339 \pm 0.0174 \mathrm{a}$ & $6.046 \pm 0.591 \mathrm{c}$ \\
& 15 & $66.2 \pm 0.5 \mathrm{a}$ & $71.9 \pm 0.5 \mathrm{a}$ & $77.4 \pm 0.6 \mathrm{a}$ & $11.2 \pm 0.3 \mathrm{a}$ & $0.1204 \pm 0.0134 \mathrm{a}$ & $6.551 \pm 0.461 \mathrm{c}$ \\
& 25 & $65.7 \pm 0.9 \mathrm{a}$ & $71.5 \pm 0.5 \mathrm{a}$ & $77.4 \pm 0.5 \mathrm{a}$ & $11.7 \pm 0.3 \mathrm{a}$ & $0.1367 \pm 0.0166 \mathrm{a}$ & $6.498 \pm 0.327 \mathrm{c}$ \\
& 35 & $66.2 \pm 0.4 \mathrm{a}$ & $71.7 \pm 0.2 \mathrm{a}$ & $77.5 \pm 0.2 \mathrm{a}$ & $11.3 \pm 0.6 \mathrm{a}$ & $0.1286 \pm 0.0118 \mathrm{a}$ & $7.498 \pm 0.261 \mathrm{~b}$ \\
& $40-35$ & $66.5 \pm 0.6 \mathrm{a}$ & $71.7 \pm 0.8 \mathrm{a}$ & $77.8 \pm 0.4 \mathrm{a}$ & $11.3 \pm 0.5 \mathrm{a}$ & $0.1208 \pm 0.0166 \mathrm{a}$ & $8.216 \pm 0.432 \mathrm{a}$ \\
\cline { 2 - 7 } & 4 & $64.2 \pm 0.7 \mathrm{a}$ & $70.6 \pm 0.2 \mathrm{a}$ & $76.4 \pm 0.3 \mathrm{a}$ & $12.3 \pm 0.6 \mathrm{a}$ & $0.1050 \pm 0.0072 \mathrm{ab}$ & $6.125 \pm 0.541 \mathrm{c}$ \\
& 15 & $64.3 \pm 0.4 \mathrm{a}$ & $70.6 \pm 0.2 \mathrm{a}$ & $76.5 \pm 0.1 \mathrm{a}$ & $12.3 \pm 0.3 \mathrm{a}$ & $0.1069 \pm 0.0081 \mathrm{ab}$ & $6.402 \pm 0.919 \mathrm{c}$ \\
& 25 & $64.1 \pm 0.4 \mathrm{a}$ & $70.8 \pm 0.1 \mathrm{a}$ & $76.2 \pm 0.9 \mathrm{a}$ & $12.0 \pm 0.5 \mathrm{a}$ & $0.1286 \pm 0.0136 \mathrm{a}$ & $7.868 \pm 0.422 \mathrm{ab}$ \\
& 35 & $64.6 \pm 0.2 \mathrm{a}$ & $70.9 \pm 0.3 \mathrm{a}$ & $76.4 \pm 0.2 \mathrm{a}$ & $11.8 \pm 0.4 \mathrm{a}$ & $0.1267 \pm 0.0158 \mathrm{a}$ & $8.289 \pm 0.741 \mathrm{a}$ \\
& $40-35$ & $64.7 \pm 0.8 \mathrm{a}$ & $70.7 \pm 0.5 \mathrm{a}$ & $77.1 \pm 0.7 \mathrm{a}$ & $12.1 \pm 0.2 \mathrm{a}$ & $0.1339 \pm 0.0174 \mathrm{a}$ & $9.014 \pm 0.846 \mathrm{a}$ \\
\hline
\end{tabular}

$\mathrm{T}_{\mathrm{o}}$, onset of gelatinaiztion; $\mathrm{T}_{\mathrm{p}}$, peak temp.; $\mathrm{T}_{\mathrm{c}}$, conclusion temp.; $\Delta \mathrm{H}$, enthalpy of gelatinization; Data are given as the mean $\pm \mathrm{SD}$ for triplicate.

Table 5 shows the effect of storage temperature on the thermal properties of rice flour ground from three japonica paddy. With increase in storage temperature, the onset temp. $\left(T_{o}\right)$, peak temp. $\left(T_{p}\right)$, and conclusion temp. $\left(T_{c}\right)$ of three paddies, as well as peak width and peak enthalpy, all changed insignificantly, but their flour gelatinization enthalpy clearly increased. The values of $T_{0}, T_{p}$ and $T_{c}$ for Changyou were markedly lower than those of Wuyunjing and Yanfeng. The gelatinization enthalpy of Changyou was slightly lower than those of Wuyunjing and Yanfeng. The values of $T_{o}, T_{p}, T_{c}$ and gelatinization enthalpy of Wuyunjing was similar to those of Yanfeng.

Table 6. DSC data for purified starch from rice flour after paddy storage for eighteen months

\begin{tabular}{llllllll}
\hline $\begin{array}{l}\text { Rice } \\
\text { Variety }\end{array}$ & $\begin{array}{l}\text { Storage } \\
\text { temp. } \\
\left({ }^{\circ} \mathrm{C}\right)\end{array}$ & $\begin{array}{l}\mathrm{T}_{\mathrm{o}} \\
\left({ }^{\circ} \mathrm{C}\right)\end{array}$ & $\begin{array}{l}\mathrm{T}_{\mathrm{p}} \\
\left({ }^{\circ} \mathrm{C}\right)\end{array}$ & $\begin{array}{l}\mathrm{T}_{\mathrm{c}} \\
\left({ }^{\circ} \mathrm{C}\right)\end{array}$ & $\begin{array}{l}\text { Peak } \\
\text { width } \\
\left({ }^{\circ} \mathrm{C}\right)\end{array}$ & $\begin{array}{l}\text { Peak } \\
\text { enthalpy } \\
(\mathrm{W} / \mathrm{mg})\end{array}$ & $\begin{array}{l}\Delta \mathrm{H} \\
(\mathrm{J} / \mathrm{g} \text { starch })\end{array}$ \\
\hline $\mathrm{CY}$ & 4 & 60.1 & 64.9 & 71.4 & 11.3 & 0.1531 & 7.055 \\
& 35 & 60.2 & 65.4 & 70.6 & 10.4 & 0.1665 & 7.210 \\
WYJ & 4 & 68.3 & 72.3 & 77.5 & 9.2 & 0.2129 & 8.738 \\
& 35 & 66.2 & 71.4 & 76.9 & 10.7 & 0.1847 & 8.748 \\
YF & 4 & 66.4 & 71.3 & 76.7 & 10.3 & 0.1757 & 8.072 \\
& 35 & 67.1 & 71.9 & 77.6 & 10.5 & 0.1841 & 8.342
\end{tabular}

$\mathrm{T}_{\mathrm{o}}$, onset of gelatinaiztion; $\mathrm{T}_{\mathrm{p}}$, peak temp.; $\mathrm{T}_{\mathrm{c}}$, conclusion temp.; $\Delta \mathrm{H}$, enthalpy of gelatinization; Data are given as the mean for two determinations. 
In order to preclude the influence of lipid, protein, cellulose, and hemicellulose, as well as soluble sugars and minerals on starch thermal property, we used purified rice starch to analyze DSC data. It was confirmed that the gelatinization enthalpy of rice starch from paddy stored at $4{ }^{\circ} \mathrm{C}$ tended to be lower than that stored at $35{ }^{\circ} \mathrm{C}$ (Table 5). The values of $T_{o}, T_{p}, T_{c}$, peak width, and enthalpy of gelatinization in purified rice starch were similar to those of brown rice flour, but its peak enthalpy markedly increased. The value of $T_{o}, T_{p}$ and $T_{c}$ in purified starch of Changyou were markedly lower than those of Wuyunjing and Yanfeng. The enthalpy of gelatinization in purified starch of Changyou was slightly lower than those of Wuyunjing and Yanfeng. The values of $T_{o}, T_{p}$, $\mathrm{T}_{\mathrm{c}}$ and enthalpy of gelatinization in purified starch of Wuyunjing was similar to those of Yanfeng.

\subsection{Changes in Mixolab Dough Pasting Properties of Paddy}

Table 7 shows the effect of storage temperature on mixolab dough pasting properties of paddy after 18-month storage. The first part of the curve in Figure 1, before the heating-cooling cycle starts, allows water absorption of the flours to be determined. The water addition level of kneading dough was constant $60 \%$ or $65 \%$ flour basis for three rice varieties. The dough development time (DDT) increased as the storage temperature of paddy increased. Compared to $15{ }^{\circ} \mathrm{C}$ storage, $\mathrm{C} 1$ consistency peak torque $(\mathrm{Nm})$ reduced as the storage temperature of paddy increased. The amplitude of kneading dough (AKD) at $30{ }^{\circ} \mathrm{C}$ was in the range of $0.02 \mathrm{Nm}$ to $0.04 \mathrm{Nm}$ for three rice varieties. Dough stability time ( $\mathrm{min}$ ) shows the dough behavior during mixing, which increased as the storage temperature of paddy increased.

Table 7. Mixolab pasting properties of rice flours from paddy

\begin{tabular}{|c|c|c|c|c|c|c|c|c|c|c|c|c|c|}
\hline $\begin{array}{l}\text { Paddy } \\
\text { Var. }\end{array}$ & $\begin{array}{l}\text { Storage temp. } \\
\left({ }^{\circ} \mathrm{C}\right)\end{array}$ & $\begin{array}{l}\text { Water } \\
\text { level\% }\end{array}$ & $\begin{array}{l}\text { DDT } \\
(\min )\end{array}$ & $\begin{array}{l}\mathrm{C} 1 \\
\text { torque } \\
(\mathrm{Nm})\end{array}$ & $\begin{array}{l}\text { AKD } \\
(\mathrm{Nm})\end{array}$ & $\begin{array}{l}\text { DST } \\
(\mathrm{min})\end{array}$ & $\begin{array}{l}\mathrm{C} 2 \\
\text { torque } \\
(\mathrm{Nm})\end{array}$ & $\begin{array}{l}\mathrm{C} 1-\mathrm{C} 2 \\
(\mathrm{Nm})\end{array}$ & $\begin{array}{l}\mathrm{C} 3 \\
\text { Torque } \\
(\mathrm{Nm})\end{array}$ & $\begin{array}{l}\mathrm{C} 4 \\
\text { torque } \\
(\mathrm{Nm})\end{array}$ & $\begin{array}{l}\mathrm{C} 3-\mathrm{C} 4 \\
(\mathrm{Nm})\end{array}$ & $\begin{array}{l}\mathrm{C} 5 \\
\text { torque } \\
(\mathrm{Nm})\end{array}$ & $\begin{array}{l}\mathrm{C} 5-\mathrm{C} 4 \\
(\mathrm{Nm})\end{array}$ \\
\hline \multirow{5}{*}{$\mathrm{CY}$} & 4 & 65 & 2.03 & 0.29 & 0.02 & 3.63 & 0 & 2.03 & 1.59 & 0.86 & 0.73 & 1.37 & 0.51 \\
\hline & 15 & 60 & 1.52 & 0.75 & 0.04 & 2.93 & 0.23 & 1.29 & 1.77 & 1.16 & 0.61 & 1.81 & 0.65 \\
\hline & 25 & 60 & 2.08 & 0.42 & 0.03 & 5.93 & 0.13 & 1.95 & 1.86 & 1.1 & 0.76 & 1.73 & 0.63 \\
\hline & 35 & 60 & 6.35 & 0.58 & 0.04 & 9.1 & 0.37 & 5.98 & 2.18 & 1.32 & 0.86 & 1.98 & 0.66 \\
\hline & $40-35$ & 60 & 5.77 & 0.33 & 0.04 & 8.5 & 0.17 & 5.6 & 1.96 & 1.17 & 0.79 & 1.8 & 0.63 \\
\hline \multirow{5}{*}{ WYJ } & 4 & 65 & 2.62 & 0.55 & 0.02 & 5.87 & 0.24 & 2.38 & 1.66 & 1.16 & 0.5 & 1.68 & 0.52 \\
\hline & 15 & 60 & 1.8 & 0.6 & 0.03 & 6.03 & 0.19 & 1.61 & 1.68 & 1.2 & 0.48 & 1.78 & 0.58 \\
\hline & 25 & 60 & 2.78 & 0.3 & 0.03 & 8.7 & 0.07 & 2.71 & 1.74 & 1.13 & 0.61 & 1.75 & 0.62 \\
\hline & 35 & 60 & 6.63 & 0.31 & 0.03 & 9.85 & 0.13 & 6.5 & 1.9 & 1.23 & 0.67 & 1.89 & 0.76 \\
\hline & $40-35$ & 60 & 4.83 & 0.31 & 0.03 & 8.22 & 0.09 & 4.74 & 1.75 & 1.17 & 0.58 & 1.82 & 1.65 \\
\hline \multirow{5}{*}{ YF } & 4 & 65 & 2.88 & 0.32 & 0.02 & 6.32 & 0.12 & 2.76 & 1.52 & 1 & 0.52 & 1.44 & 0.44 \\
\hline & 15 & 60 & 1.97 & 0.41 & 0.03 & 5.48 & 0.1 & 1.87 & 1.68 & 1.12 & 0.56 & 1.7 & 0.58 \\
\hline & 25 & 60 & 4.55 & 0.33 & 0.02 & 7.12 & 0.07 & 4.48 & 1.8 & 1.16 & 0.64 & 1.79 & 0.63 \\
\hline & 35 & 60 & 5.13 & 0.26 & 0.03 & 9.1 & 0.04 & 5.09 & 1.78 & 1.13 & 0.65 & 1.7 & 0.57 \\
\hline & $40-35$ & 65 & 5.17 & 0.57 & 0.02 & 9.85 & 0.32 & 0.25 & 2.32 & 1.56 & 0.76 & 2.29 & 1.13 \\
\hline
\end{tabular}

Note: Water level\%, constant water level (\%flour basis); DDT, dough development time (min); C1, consistency peak torque (Nm); AKD, amplitude of kneading dough (Nm); DST, dough stability time (min); C2, consistency minimum torque (Nm); C1-C2, protein weakness; $\mathrm{C}$, pasting viscosity peak torque (Nm); C4, pasting viscosity minimum torque $(\mathrm{Nm})$; $\mathrm{C} 3-\mathrm{C} 4$, starch decay $(\mathrm{Nm})$; $\mathrm{C} 5$, starch retrogradation final torque $(\mathrm{Nm})$; C5-C4,Starch setback $(\mathrm{Nm})$. 

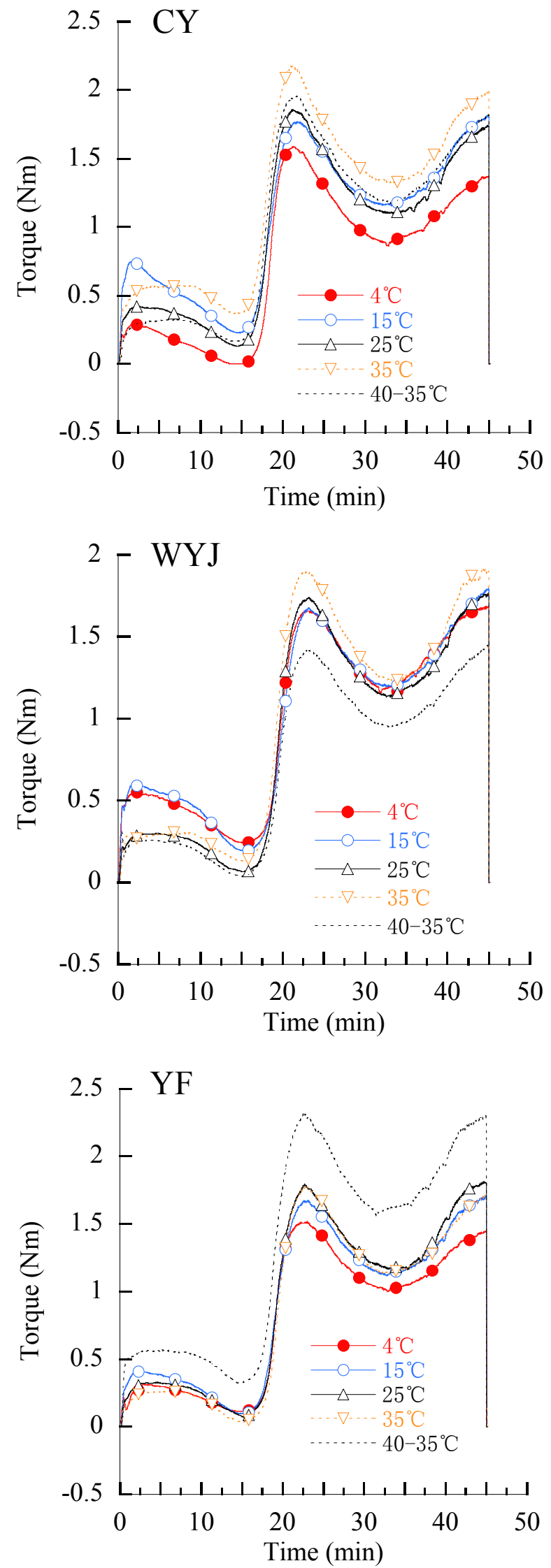

Figure 1. Mixolab analysis of brown rice dough behavior during mixing, heating and cooling 
The minimum torque (C2) of dough consistency is related to weakening of the protein network from mechanical and thermal constraints. The high $\mathrm{C} 2$ minimum torque shows strong protein network. At five storage temperatures, $\mathrm{C} 2$ minimum torque was in the range of 0.01 to $0.37 \mathrm{Nm}, 0.07$ to $0.24 \mathrm{Nm}$ and 0.04 to $0.12 \mathrm{Nm}$ for Changyou, Wuyunjing and Yanfeng, respectively. Protein weakness (C1-C2) increased with an increase in storage temperature of three varieties of paddy.

The second part of the curve shows the behavior of rice starch gelatinization. C3 pasting viscosity peak (Nm) shows starch gelatinization rate, which increased as the storage temperature of paddy increased, but $\mathrm{C} 4$ pasting viscosity minimum torque $(\mathrm{Nm})$ and $\mathrm{C} 5$ starch retrogradation end $(\mathrm{Nm})$ tended to increase. In contrast to lower temperature storage, higher temperature storage increased starch gelatinization peak $(\mathrm{C} 3)$, starch gelatinization minimum (C4), starch retrogradation minimum (C5), degrees of starch decay (C3-C4) and setback (C5-C4).

\section{Discussion}

Fat acidity is usually used as an index of quality deterioration during rice storage since lipid dissolution is considered to be more rapidly than protein and starch (Genkawa et al., 2008). This study showed that long $35^{\circ} \mathrm{C}$ storage seemed to increase FFA content, but significantly decreased oleic acid content compared with $4{ }^{\circ} \mathrm{C}$ storage. This demonstrated that the rice triglycerides were degraded during storage. These changes might involve the hydrolysis of lipids to produce FFA and the oxidation of lipids (including FFA) into hydroperoxides and other secondary products (Gregory et al., 2008). Yasumatsu et al. (1964) suggested that FFA quantity increased during storage and bind with amylose in starch, and the increase in fatty acid-amylose complex may affect the maximum viscosity of the amylogram. Hence, the increase of FFA content in paddy during long time storage (over 15 months) should be cautious to adopt, and other sensitive indicator is need to explore.

The duration and temperature of storage were found to markedly affect the enthalpy and temperature of gelatinization and retrogradation of rice flour (Fan \& Marks, 1999). Starch and in particular, amylose became more insoluble following the higher temperature storage (Rajendra \& Zakiuddin, 1991; Patindol et al., 2005; Zhou et al., 2007). The RVA pasting curves of rice flours have shown that the changes in pasting properties of milled rice during storage contained increased setback (Sowbhagya and Bhattacharya, 2001) and decreased breakdown(Zhou et al., 2003; Park et al., 2012). In this study, compared to lower temperate $\left(4\right.$ and $\left.15{ }^{\circ} \mathrm{C}\right)$, the higher storage temperature $\left(35^{\circ} \mathrm{C}\right)$ increased the enthalpy of paddy flour gelatinization determined by a differential scanning calorimetry (DSC) and decreased damaged starch, also increased Mixolab characteristic torque parameters such as starch gelatinization peak (C3), starch gelatinization minimum (C4), starch retrogradation minimum (C5), degrees of starch decay (C3-C4) and retrogradation (C5-C4) with a decrease in protein weakening $(\mathrm{C} 2)$. This suggested that longtime higher temperature storage lead to more ordered structure of deteriorated rice, reducing the swelling and cracking of starch granula and leaking of starch components. This change in aged rice thermal behaviors maybe increase optimum cooking time. Interestingly, from the DSC thermograms we found the gelatinization enthalpy of rice purified starch from $4{ }^{\circ} \mathrm{C}$ storage tended to be higher than that of $35^{\circ} \mathrm{C}$ long storage. This indicates the effect of storage on rice thermal properties relates to the interaction between starch and non-starch components after long storage. The effect of non-starch components such as protein and non-starch polysaccharides on the thermal properties of ageing rice need further study.

\section{Conclusion}

After 18-month storage, the paddy stored at or below $25{ }^{\circ} \mathrm{C}$ had more than $70 \%$ germination rate, their flour extracts by acid dye mixture of methyl red and bromothymol blue showed greenish color, but the paddy stored at $35^{\circ} \mathrm{C}$ was only $30 \%$ germination rates, their flour extracts by acid dye mixture seem to be yellowish. With an increase in storage temperature, moisture content in paddy decreased. The content of oleic acid in paddy stored at $4{ }^{\circ} \mathrm{C}$ was markedly higher than that at the temperatures of 15,25 and $35^{\circ} \mathrm{C}$. Compared to lower temperate $(4$ and $15{ }^{\circ} \mathrm{C}$ ), the higher storage temperature $\left(35^{\circ} \mathrm{C}\right)$ increased the enthalpy of paddy flour gelatinization determined by a differential scanning calorimetry (DSC), also increased Mixolab characteristic torque parameters such as starch gelatinization peak (C3), starch gelatinization minimum (C4), starch retrogradation minimum (C5), degrees of starch decay (C3-C4) and retrogradation (C5-C4) with a decrease in protein weakening (C2). The results of this study indicate storage temperature is an important factor affecting the physiological and physicochemical properties of paddy, and lower temperature below room temperature are recommended to maintain paddy quality.

\section{Acknowledgements}

The authors gratefully acknowledge the Special Fund for Grain Scientific Research in the Public Interest from the State Administration of Grains, China (201313001-03-01). 


\section{Reference}

Blumenkrantz, N., \& Asboe-Hansen G. (1973). New method for quantitative determination of uronic acid. Analytical Biochemistry, 54(2), 484-489. http://dx.doi.org/10.1016/0003-2697(73)90377-1

Cao, Z. Y., Wei, Z. Y., \& Li, X. J. (2009). Effect of high temperature and high humidity on the germination and contents of sugars, protein and amino acids of rice grains. Journal of Henan University of Technology (Natural Science Edition), 30(1), 22-28 (In Chinese with English abstract).

Dhaliwal, Y. S., Sekhon, K. S., \& Nagi, H. P. (1991). Enzymatic activities and rheological properties of stored rice. Cereal Chemistry, 68(1), 18-21.

Dubois, M., Gilles, K. A., Hamilton, J. K., Rebers, P. A., \& Smith, F. (1956). Colorimetric method for determination of sugars and related substances. Analytical Chemistry, 28(3), 350-356. http://dx.doi.org/10.1021/ac60111a017

Fan, J., \& Marks, B. P. (1999). Effects of rough rice storage conditions on geletiniaztion and retrogradation $\begin{array}{llllll}\text { properties of rice flours. Cereal } & \text { Chemistry, }\end{array}$ http://dx.doi.org//10.1094/CCHEM.1999.76.6.894

Genkawa, T., Uchino, T., Inoue, A., Tanaka, F., \& Hamanaka, D. (2008). Development of a low-moisture content storage system for brown rice: storability at decreased moisture contents. Biosystems Engineering, 99(4), 515-522. http://dx. doi.org/ 0.1016/j.biosystemseng.2007.12.011

Goffman, F. D., \& Bergman, C. (2003). Hydrolytic degradation of triacyglycerols and changes in fatty acid composition in rice bran during storage. Cereal Chemistry, 80(4), 459-461. $\mathrm{http}: / / \mathrm{dx}$.doi.org/10.1094/CCHEM.2003.80.4.459

Gregory, A. G., Toshitaka, U., Fumihiko, T., \& Daisuke, H. (2008). Effect of vapors from fractionated samples of propolis on microbial and oxidation damage of rice during storage. Journal of Food Engineering, 88(3), 341-352. http://dx.doi.org/10.1016/j.jfoodeng.2008.02.019

Jang, E. H., Lim, S. T., \& Kim, S. S. (2009). Effect of storage temperature for paddy on consumer perception of cooked rice. Cereal Chemistry, 86(5), 549-555. http://dx.doi.org/10.1094/CCHEM-86-5-0549

Likitwattanasade, T., \& Hongsprabhas, P. (2010). Effect of storage proteins on pasting properties and microstructure of Thai rice. Food Research International, 43(5), 1402-1409. http://dx.doi.org/10.1016/j.foodres.2010.04.011

Meullenet, J. F., Marks, B. P., Hankins, J. A., Griffin, V. K., \& Daniels, M. J. (2000). Sensory quality of cooked long-grain rice as affected by rough rice moisture content, storage temperature, and storage duration. Cereal Chemistry, 77(2), 259-263. http://dx.doi.org/10.1094/CCHEM.2000.77.2.259

Noomhorm, A., Kongseree, N., \& Apintanapong, N. (1997). Effect of aging on the quality of glutinous rice crackers. Cereal Chemistry, 74(1), 12-15. http://dx.doi.org/10.1094/CCHEM.1997.74.1.12

Park, C. E., Kim, Y. S., Park, K. J., \& Kim, B. K. (2012). Changes in physicochemical characteristics of rice during storage at different temperatures. Journal of stored products research, 48(1), 25-29. http://dx.doi.org/10.1016/j.jspr.2011.08.005

Patindol, J., Wang, W. J., \& Jane, J. I. (2005). Structure-functionality changes in starch following rough rice storage. Starch/Stärke, 57(5), 197-207. http://dx.doi.org/ 10.1002/star.200400367

Pearce, M. D., Marks, B. P., \& Meullenet, J. F. (2001). Effects of postharvest parameters on functional changes during rough rice storage. Cereal Chemistry, 78(3), 354-357. http://dx.doi.org/10.1094/CCHEM.2001.78.3.354

Perdon, A. A., Marks, B. P., Siebenmorgen, T. J., \& Reid, N. B. (1997). Effect of rough rice storage conditions on the amylograph and cooking properties of medium-grain rice cv. Bengal. Cereal Chemistry, 74(6), 864-867. http://dx.doi.org/10.1094/CCHEM.1997.74.6.864

Perdon, A. A., Siebenmorgen, T. J., Buescher, R. W., \& Gbur, E. E. (1999).Starch retrogradation and texture of cooked milled rice during storage. Journal of Food Science, 64(5), 828-832. http://dx.doi.org/10.1111/j.1365-2621.1999.tb15921.x

Rajendra, K. K., \& Zakiuddin, A. S. (1991). Properties of rice starch from paddy stored in cold and at room temperature. Starch/Stärke, 43(5), 165-168. http://dx.doi.org/ 10.1002/star.19910430502 
Rosell, C. M., Collar, C., \& Haros, M. (2007). Assessment of hydrocolloid effects on the thermo-mechanical properties of wheat using the Mixolab. Food Hydrocolloids, 21(3), 452-462. http://dx.doi.org/10.1016/j.foodhyd.2006.05.004

Sodhi, N. S., Singh, N., Arora, M., \& Sing, J. (2003). Changes in physicochemical, thermal, cooking and textural properties of rice during aging. Journal of Food Processing and Preservation, 27(5), 387-400. http://dx.doi.org/ 10.1111/j.1745-4549.2003.tb00525.x

Singh, N., Kaur, L., Sandhu, K. S., Kaur, J., \& Nishinari, K. (2006). Relationships between physicochemical morphological, thermal, rheological properties of rice starch. Food Hydrocolloids, 20(4), 532-542. http://dx.doi.org/10.1016/j.foodhyd.2005.05.003

Sowbhagya, C. M., \& Bhattacharya, K. R. (2001). Changes in pasting behaviour of rice during ageing. Journal of Cereal Science, 34(2), 115-124. http://dx.doi: 10.1006/jcrs.2001.0371

Suzuki, Y., Ise, K., Li, C., Honda, I., Iwai, Y., \& Matsukura, U. (1999). Volatile components in stored rice (Oryza sativa L.) of varieties with and without lipolygenase-3 in seeds. Journal of Agricultural and Food Chemistry, 47(3), 1119-1124. http://dx.doi.org/ 10.1021/jf980967a

Teo, C. H., Abd, A., Cheah, P. B., Norziah, M. H., \& Seow, C. C. (2000). On the role of protein and starch in the aging of non-waxy rice flour. Food Chemistry, 69(3), 229-236. http://dx.doi.org/10.1016/S0308-8146(99)00271-X

Yang, C. Z., Shu, X. L., Zhang, L. L., Wang, X. Y., Zhao, H. J., Ma, C. X., \& Wu, D. X. (2006). Starch properties of mutant rice high in resistant starch. Journal of Agricultural and Food Chemistry, 54(2), 523-528. http://dx. doi.org/ 10.1021/jf0524123

Yasumatsu, K., Moritaka, S., \& Kakinuma, T. (1964). Effect of the change during storage in lipid composition of rice on its amylogram. Agricultural and Biological Chemistry, 28, 265-272.

Zhang, Y. D., Li, X. J., \& Qin, W. (2012). Changes in contents of proteins and activity of polyphenol oxidase in newly harvested rough rice during storage. Food Science and Technology, 37(1)150-154,159 (In Chinese with English abstract).

Zhou, Z. K., Robards, K., Helliwell, S., \& Blanchard. C. (2002). Ageing of stored rice: Changes in chemical and physical attributes. Journal of Cereal Science, 35(1), 65-78. http://dx.doi.org/ 10.1006/jcrs.2001.0418

Zhou, Z. K., Robards, K., Helliwell, S., \& Blanchard, C. (2010). Effect of storage temperature on rice thermal properties. Food Research International, 43(3), 709-715. http://dx.doi.org/10.1016/j.foodres.2009.11.002

Zhou, Z. K., Robards, K., Helliwell, S., \& Blanchard, C. (2003). Effect of rice storage temperature on pasting properties of rice flour. Food Research International, 36(3), 625-634. http://dx.doi:10.1016/S0963-9969(03)00013-9

Zhou, Z. K., Robards, K., Helliwell, S., \& Blanchard, C. (2007). Effect of storage temperature on cooking behaviour of rice. Food Chemistry, 105(2), 491-497. http://dx.doi.org/10.1016/j.foodchem.2007.04.005

\section{Copyrights}

Copyright for this article is retained by the author(s), with first publication rights granted to the journal.

This is an open-access article distributed under the terms and conditions of the Creative Commons Attribution license (http://creativecommons.org/licenses/by/3.0/). 